\title{
Is cyanophycin involved in the integration of nitrogen and carbon metabolism in the cyanobacteria Anabaena cylindrica and Gloeothece grown on light/dark cycles?
}

\author{
Alison H. Mackerras, Bernadette N. Youens, Ronald C. Weir and Geoffrey D. Smith* \\ Department of Biochemistry, Faculty of Science, The Australian National University, GPO Box 4, Canberra, ACT 2601, \\ Australia
}

(Received 19 December 1989; revised 30 April 1990; accepted 6 July 1990)

\begin{abstract}
In Anabaena cylindrica, protein synthesis continued during dark periods at $80 \%$ of the rate observed in the light. Since nitrogen fixation ceases in the dark, this implies that fixed nitrogen accumulates during the light periods to supply amino acids for protein synthesis in the dark. Measurements of cyanophycin and the distribution of nitrogen in subcellular fractions indicated that cyanophycin does not represent a significant proportion of total cell nitrogen, nor does its concentration vary across the light/dark cycle. Similar results were obtained with Gloeothece; there was no evidence that cyanophycin accumulated during the dark to support protein synthesis in the light. Cyanophycin does not, therefore, appear to serve as a dynamic temporary storage form of newly fixed nitrogen in the integration of light and dark metabolism. We also investigated an immunological approach to the measurement of cyanophycin and its turnover. Cyanophycin is immunogenic, and in the pure state could be assayed by radioimmunoassay, which had greater sensitivity than traditional assay procedures. The insolubility of cyanophycin at neutral pH, however, prevented the successful development of methods for quantifying cyanophycin turnover in cell extracts.
\end{abstract}

\section{Introduction}

Cyanobacteria are unique in that they are capable of both nitrogen fixation and oxygenic photosynthesis. The oxygen sensitivity of nitrogenase requires that these processes be separated in nitrogen-fixing cyanobacteria. Heterocystous cyanobacteria achieve this by confining nitrogen fixation to heterocysts while $\mathrm{CO}_{2}$ fixation occurs in vegetative cells. Thus a spatial separation exists between the two processes. When heterocystous organisms such as Anabaena cylindrica are grown on light/dark (L/D) cycles, both $\mathrm{CO}_{2}$ and nitrogen fixation occur in the light. In contrast, non-heterocystous cyanobacteria, such as Gloeothece and Synechococcus, separate $\mathrm{CO}_{2}$ and nitrogen fixation temporally (Mullineaux et al., 1981 $a$; Mitsui et al., 1986). When these organisms are grown on $\mathrm{L} / \mathrm{D}$ cycles, nitrogen fixation occurs in the dark, and $\mathrm{CO}_{2}$ fixation occurs in the light.

Balanced growth has been defined as the state where the concentrations of all cellular components increase at

Abbreviations: butyl-PBD, 2(4'-t-butylphenyl)-5-(4"-biphenylyl)1,3,4-oxadiazole; TBS, Tris-buffered saline; TTBS, TBS containing $0 \cdot 1 \%$ Triton $X-100 ; L / D$, light/dark. the same rate (Shuter, 1979), and if an organism is to achieve this, nutrients must be provided in the correct proportions at the appropriate time and place (Carr, 1988; Romero \& Lara, 1987). In this paper, balanced growth during L/D cycles is defined as the synthesis of protein, nucleic acids, chlorophyll and structural carbohydrate. It does not include the glycogen synthesized during light periods, which is used to provide energy to support cellular processes in the dark (cf. Mur, 1983). Because the strategies adopted by nitrogen-fixing cyanobacteria to protect nitrogenase from oxygen involve the separation of nitrogen and carbon fixation, if growth is to occur throughout the L/D cycle the supplies of fixed carbon and nitrogen must be appropriately regulated. Fixed carbon can be stored temporarily in the form of sugars and glucan, and Foy \& Smith (1980) showed that two Oscillatoria species incubated under L/D cycles continued to grow in the dark at the expense of glycogen accumulated during the preceding light period. The supply of nitrogen required for protein synthesis in the dark also depended partly on nitrate taken up during the light, which implies that the nitrogen was stored in some form. The nature of this temporary storage form of fixed nitrogen is not yet known. 
If nitrogen-fixing $A$. cylindrica were to continue growing during the dark phase of a L/D cycle it would also need a supply of fixed nitrogen in addition to the supply of glycogen, since nitrogen fixation ceases in the dark in this strain (Mullineaux et al., 1981 a). In contrast, Gloeothece fixes nitrogen in the dark at the expense of glycogen accumulated in the light. The supply of glycogen is limited, however, and protein synthesis measurements in Gloeothece have indicated that most protein synthesis occurs in the light (Mullineaux et al., $1981 b$ ). Therefore it would appear that both $A$. cylindrica and Gloeothece need to be able to accumulate a temporary store of fixed nitrogen to buffer their metabolism against the interruptions in nutrient supply which growth on $L / D$ cycles imposes.

The experiments described in this paper investigate the possibility that cyanophycin might act as a temporary store of fixed nitrogen in the integration of nitrogen fixation and photosynthesis. Cyanophycin is the copolymer of aspartate and arginine, first isolated by Simon (1971). Most cyanobacteria accumulate cyanophycin at some point in their growth cycle (Lawry \& Simon, 1982, Allen, 1984). Simon (1973) showed that cyanophycin accumulated in stationary-phase $\boldsymbol{A}$. cylindrica and that it was degraded when such cells were used to reinitiate growth. He proposed that cyanophycin served as a nitrogen reserve under these conditions. It has also been suggested that cyanophycin may serve as a dynamic reservoir of newly fixed nitrogen to buffer nitrogenfixing cells against fluctuations in environmental supply (Carr, 1983, 1988; Carr \& Wyman, 1986). This hypothesis is based on the observation that both the synthetic and degrading enzymes for cyanophycin are more active in heterocysts of nitrogen-fixing Anabaena species than in the vegetative cells (Gupta \& Carr, 1981). Carr (1983) proposed that "cyanophycin serves, in both heterocysts and vegetative cells, as a reservoir of newly assimilated nitrogen' which is then used for other cell processes. This hypothesis would make cyanophycin an integral part of the interplay between nitrogen and carbon metabolism.

The aim of the experiments reported in this paper was to establish whether cyanophycin levels altered during the L/D cycle in a manner consistent with cyanophycin acting as a temporary store of fixed nitrogen. The paper reports measurements of growth, protein synthesis, nitrogen incorporation and cyanophycin levels made in $A$. cylindrica grown on $\mathrm{L} / \mathrm{D}$ cycles under nitrogen-fixing conditions and measurements of nitrogen incorporation and cyanophycin levels in Gloeothece grown similarly.

The investigation of cyanophycin metabolism has been hampered by the lack of specificity and relative insensitivity of the assay procedure (Simon, 1987). This has been a continuing problem in our work with cyanophycin (for example see Daday et al., 1988). Simon
(1987) has reported that cyanophycin is antigenic and this paper also reports our attempts to develop suitable immunoassays for cyanophycin.

\section{Methods}

Cyanobacterial growth. A. cylindrica (ATCC 27899) was obtained from the American Type Culture Collection and grown as previously described (Daday et al., 1977, 1985) in the medium of Allen \& Arnon (1955) diluted eightfold for all components except phosphate (full strength, $2 \mathrm{mM})$ and $\mathrm{NiSO}_{4}(4 \times$ full-strength, $0.68 \mu \mathrm{M})$ at a light density of $150 \mu \mathrm{E} \mathrm{m}^{-2} \mathrm{~s}^{-1}$. Cultures were sparged with $0.3 \% \mathrm{CO}_{2}$ in air or in air alone as specified for individual experiments. Gloeothece (ATCC 27152) was obtained from the American Type Culture Collection. Sheathless Gloeothece (PCC 6909-1, Kallas et al., 1983) was a gift from Dr J. Gallon, Swansea, UK. Both strains were grown in fullstrength Allen \& Arnon (1955) medium supplemented with $0.5 \mathrm{~mm}$ $\mathrm{NaHCO}_{3}$ and $4 \times$ full-strength $\mathrm{NiSO}_{4}(0.68 \mu \mathrm{M})$. Cells were sparged with air and grown at a light intensity of $20 \mu \mathrm{E} \mathrm{m}^{-2} \mathrm{~s}^{-1}$ (photosynthetically active radiation). Both organisms were grown on $12 \mathrm{~h} \mathrm{light} / 12 \mathrm{~h}$ dark cycles. For each experiment two identical cultures were inoculated and grown with the light periods $12 \mathrm{~h}$ out of phase.

Growth measurements. Growth was measured either by light scattering with a Klett-Summerson colorimeter (no. 66 filter, Mallette, 1969), by cell dry weight (Daday et al., 1988) or by protein concentration. Protein concentrations were measured using the method of Bradford (1976), standardized with bovine plasma gamma-globulin (Bio-Rad reagents). Protein values are reported for the supernatant obtained after cells were broken with the French pressure cell (138 $\mathrm{MPa}$ ) and centrifuged at $27000 \mathrm{~g}$ for $15 \mathrm{~min}$.

Cyanophycin extraction and assay. Cyanophycin was extracted by the method of Simon (1973). Cell samples were concentrated approximately 10 -fold by centrifugation and resuspension in $10 \mathrm{mM}$-HEPES/ $\mathrm{NaOH}, 1 \mathrm{~mm}-\mathrm{Na}_{2}$ EDTA, pH 7.5. Concentrated cell suspensions were stored frozen until cyanophycin extractions were done. Thawed cells were broken by a French pressure cell at $138 \mathrm{MPa}$. The cyanophycin content in the pooled acid extracts was determined with the Sakaguchi assay for arginine (Simon, 1973; Messineo, 1966). Arginine. HCl was used as the standard. The conversion factor between measured arginine and cyanophycin was determined by amino acid analysis and arginine assay of representative samples. One microgram of arginine in the colorimetric assay corresponds to $4.2 \mu \mathrm{g}$ of cyanophycin measured by amino acid analysis.

Nitrogen content. Nitrogen was determined by a modification of the micro-Kjeldahl procedure (Bergersen, 1980; Daday et al., 1985). When ammonia was recovered by diffusion, plastic centre wells (Kontes Scientific Glassware/Instruments, cat. no. 882320-0000) were used to hold the acid-soaked filter paper strips. For some samples ammonia was determined without the diffusion procedure, as described by Bergersen (1980), except that the concentration of $\mathrm{NaOH}$ in colorimetric reagent B was $95 \mathrm{~g} \mathrm{l}^{-1}$ rather than $40 \mathrm{~g} \mathrm{l}^{-1}$.

Cells (50-100 Klett units) were concentrated approximately 10-fold by centrifugation, and resuspended in $10 \mathrm{mM}-\mathrm{KH}_{2} \mathrm{PO}_{4} / \mathrm{K}_{2} \mathrm{HPO}_{4}$, $\mathrm{pH} 7.5$. Samples $(5 \mathrm{ml})$ of the concentrated cells were used to determine whole cell $\mathrm{N}$-content. The remaining cells were frozen overnight and broken with the French pressure cell $(138 \mathrm{MPa})$. The cell-free extract was centrifuged $(27000 \mathrm{~g}, 15 \mathrm{~min})$ and the pellet and supernatant were separated. Cyanophycin was extracted from the pellet fraction (Simon, 1973) and the nitrogen content of the resulting acid extract was determined. A portion of the supernatant was made $5 \%(w / v)$ in trichloroacetic acid (TCA). The pellet from this step was resuspended 
in warm $0.5 \mathrm{M}-\mathrm{NaOH}$ (Ownby et al., 1979) and the nitrogen content was determined in appropriate samples. Aliquots of the TCA-supernatant were also assayed. All samples were dried at $85^{\circ} \mathrm{C}$ before acid digestion.

Protein synthesis in A. cylindrica. Cells were grown to 50-80 Klett units. At suitable times, duplicate $15 \mathrm{ml}$ aliquots were transferred to $25 \mathrm{ml}$ flasks, and incubated in growth cabinets with sparging. $\left[{ }^{14} \mathrm{C}\right]$ Leucine or $\left[{ }^{14} \mathrm{C}\right]$ protein hydrolysate $[2 \cdot 2 \mu \mathrm{Ci}(82 \mathrm{kBq})$ in $100 \mu \mathrm{l}$, Amersham] was added to each flask, and samples ( $100 \mu \mathrm{l}$ cells) were taken at 0, 30, 60 and $90 \mathrm{~min}$. Each sample was immediately frozen and thawed twice in liquid nitrogen, and then transferred to a glass-fibre disk. Protein was precipitated with cold $5 \%(w / v)$ TCA. Disks were washed twice with cold $5 \%(\mathrm{w} / \mathrm{v}) \mathrm{TCA}$, and three times with ethanol, then dried and transferred to scintillation vials containing $10 \mathrm{ml}$ scintillant (toluene/2-methoxyethanol, $60: 40, \mathrm{v} / \mathrm{v}$, containing $6 \mathrm{~g}$ butylPBD $~^{-1}$ ). Radioactivity incorporated into TCA-precipitable material was counted with a Beckman LS2800 scintillation counter. Counting efficiency was $80 \%$.

Antibody production. Outbred Swiss white mice were injected intraperitoneally with either $0.1 \mathrm{ml}$ cyanophycin $\left(1 \mathrm{mg} \mathrm{ml}^{-1}\right.$ emulsified in sterile $0.15 \mathrm{M}-\mathrm{NaCl}$ using a sonic cleaning bath) or $0.1 \mathrm{ml}$ cyanophycin emulsified with $0.1 \mathrm{ml}$ Freund's incomplete adjuvant (Difco). The injections were repeated after 2, 15, 22 and $29 \mathrm{~d}$. ELISA tests on serum obtained from blood via the optic plexus showed that antibodies were produced in mice which had received the cyanophycin/ adjuvant mixture. On day 26 these mice were injected with Sarcoma 180 cells (approx. $0.1 \mathrm{ml}$ of a $10 \%$ suspension) (Tikasingh et al., 1966). Antibody-rich ascitic fluid was collected after approximately 7-14 d accumulation. The ascitic fluid was defatted, pooled, and stored in $100 \mu \mathrm{l}$ aliquots at $-20^{\circ} \mathrm{C}$.

Enzyme-linked immunoassay (ELISA). ELISA assays were done in 96-well microtitration trays using standard methods. Microtitration plates were prepared by adsorbing $50 \mu \mathrm{l}$ cyanophycin $\left(40 \mu \mathrm{g} \mathrm{ml}^{-1}\right)$ in Tris-buffered saline (TBS, $10 \mathrm{~mm}-\mathrm{Tris} / \mathrm{HCl}, 50 \mathrm{~mm}-\mathrm{NaCl}, \mathrm{pH}$ 7) to each well for $1 \mathrm{~h}$ at room temperature. Unadsorbed antigen was removed by washing the wells three times with TBS. The wells were treated with $300 \mu 10.5 \%$ defatted milk powder in TBS (room temperature, $30 \mathrm{~min}$ ) to block non-specific binding, and then washed three times with $0.1 \%$ Tween 20 in TBS (TTBS). Serum or ascitic fluid was diluted into antibody buffer ( $5 \%$ milk powder in TTBS), added as appropriate to the wells and incubated for $1 \mathrm{~h}$ at room temperature. Alkaline-phosphatase-conjugated goat anti-mouse immunoglobulin solution (diluted 1 in 3000) was used with p-nitrophenol phosphate for detection of the primary antibody according to the instructions of BioRad Laboratories. The trays were screened using a Dynatech Model 2250 EIA reader.

Radioimmunobinding assay for cyanophycin. This assay was an adaptation of the methods of Davis et al. (1984) and La Duca et al. (1986). A square $(10 \times 10 \mathrm{~cm})$ of nitrocellulose membrane filter was cut and washed in distilled water for $15 \mathrm{~min}$. The filter was then marked with a soft pencil to produce a grid of squares $(1 \times 1 \mathrm{~cm})$. After a further wash (15 min) in distilled water, the filter was cut into strips (10 $\times 1 \mathrm{~cm})$ which were thoroughly dried before use. Samples $(1-5 \mu \mathrm{l})$ containing cyanophycin were spotted onto the strips; if necessary larger volumes could be applied by drying the strips between applications. Once dry, the strips could be stored at $4{ }^{\circ} \mathrm{C}$ for at least 2 months.

Prior to use, the strips were washed for $15 \mathrm{~min}$ in TBS and for $30 \mathrm{~min}$ in blocking solution ( $0.5 \%$ milk powder in TBS). Ascitic fluid was diluted 1 in 300 into antibody buffer and the strips were incubated in this solution for $90 \mathrm{~min}$ at $37^{\circ} \mathrm{C}$. The strips were washed with TTBS and then incubated with ${ }^{125} \mathrm{I}$-labelled sheep anti-mouse IgG solution [approx. $1 \mu \mathrm{Ci}(37 \mathrm{kBq})$ in $20 \mathrm{ml}$ antibody buffer] for $2 \mathrm{~h}$ at room temperature with gentle agitation. The strips were washed in five changes of TTBS over a period of $1 \mathrm{~h}$ and then allowed to dry before being cut into squares. Bound radioactivity was counted in an LKB Model 1270 Rackgamma II counter; all results are expressed as c.p.m.

\section{Results}

Patterns of growth and protein synthesis during light/dark cycles

It was first necessary to establish whether growth (as defined in the Introduction) of nitrogen-fixing $A$. cylindrica and Gloeothece occurred predominantly during light periods or across both light and dark periods. Growth measurements using the methods of light scattering, dry weight and increase in total protein were not sufficiently sensitive to give a clear answer to this question (results not shown).

Consequently, protein synthesis in the light and dark was assessed in $\boldsymbol{A}$. cylindrica by measuring the rate of incorporation of $\left[{ }^{14} \mathrm{C}\right]$ leucine or other ${ }^{14} \mathrm{C}$-labelled amino acids into TCA-precipitable material as described in Methods. The results of these measurements are shown in Fig. 1. Rates of protein synthesis in the dark were comparable to the rates in the light for both labels used.

Measurement of protein synthesis in the sheathed strain of Gloeothece (ATCC 27152) was attempted using the same procedure as used for $A$. cylindrica. However, the thick carbohydrate sheath protected the cells against lysis by freezing and thawing, and thus the washing procedures following TCA-precipitation were not effective. Since Mullineaux et al. $(1981 b)$ have reported results for protein synthesis in Gloeothece using a different method (Mullineaux et al., 1980), these experiments were not pursued.

\section{Cyanophycin levels during light/dark growth}

Growth and protein synthesis measurements with $A$. cylindrica indicated that cells need to accumulate fixed nitrogen in some form during the light period to support the protein synthesis which occurs in the dark while nitrogen fixation is not active. Results of experiments to determine if fixed nitrogen accumulated as cyanophycin are also shown in Fig. 1. Cyanophycin did not accumulate significantly in nitrogen-fixing, exponentially-growing $A$. cylindrica at any time during light or dark periods irrespective of the growth conditions used. The following growth conditions all gave similar results: $12 \mathrm{~h} \mathrm{~L} / 12 \mathrm{~h} \mathrm{D}$ sparged with air or $0.3 \% \mathrm{CO}_{2}$ in air, $12 \mathrm{~h}$ $\mathrm{L} / 12 \mathrm{~h} \mathrm{D}$ with low light intensity $\left(80 \mu \mathrm{E} \mathrm{s}^{-1} \mathrm{~m}^{-2}\right)$ and $6 \mathrm{~h}$ $\mathrm{L} / 18 \mathrm{~h} \mathrm{D}$ sparged with $0.3 \% \mathrm{CO}_{2}$ in air. The maximum value for cyanophycin shown in Fig. 1 corresponds to approximately $0 \cdot 1 \%$ of dry weight. The detection limit for cyanophycin measurements typically corresponded 


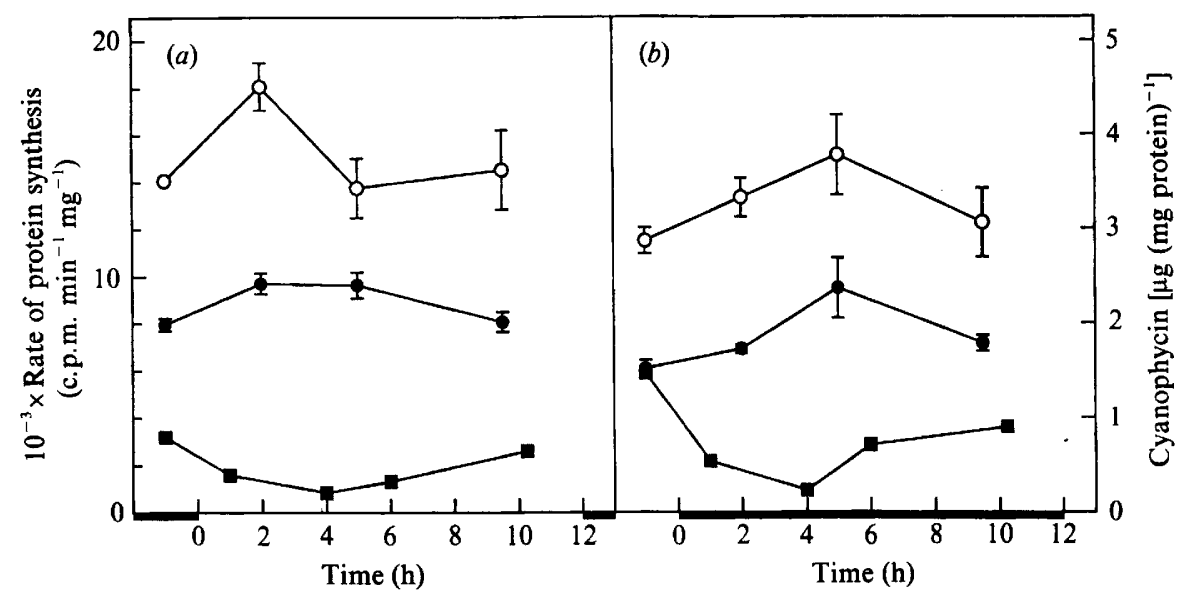

Fig. 1. Protein synthesis in nitrogen-fixing A. cylindrica. Protein synthesis was measured by incorporation of $\left[{ }^{14} \mathrm{C}\right] l$ leucine $(\Theta)$ and ${ }^{14} \mathrm{C}$ labelled amino acids $(O)$ into TCA-precipitable material. Plotted points represent rates of incorporation of label relative to cell dry weight. Initial rates of incorporation were linear for at least $60 \mathrm{~min}$. The error bars represent the standard error of these slopes. Cells were grown in air under nitrogen-fixing conditions to initial cell densities of $66 \mathrm{Klett}$ units $(a)$ and 71 Klett units $(b)$. Dry weights were measured at each time point. Cyanophycin contents of the cells are also shown $(\boldsymbol{D})$. The maximum concentration of cyanophycin shown in (b) corresponds to approximately $0.1 \%$ of dry weight. Dark bars on the $x$-axes of this and Figs. 2 and 3 indicate dark periods.

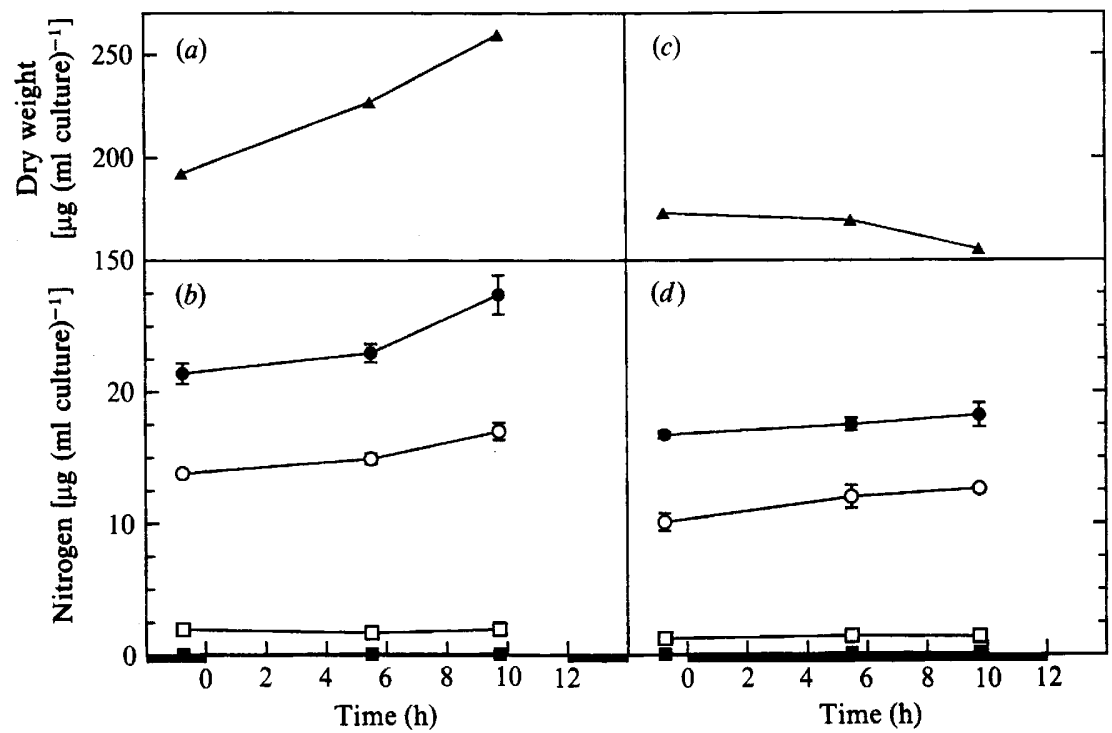

Fig. 2. Distribution of nitrogen in cell fractions of nitrogen-fixing $A$. cylindrica grown on $12 \mathrm{~h} \mathrm{~L} / 12 \mathrm{~h} \mathrm{D}$ cycles under $0 \cdot 3 \% \mathrm{CO}_{2}$ in air. Measurements were made during the light $(a, b)$ and dark $(c, d)$ periods. Initial Klett values were $82(a, b)$ and $62(c, d)$. $(a, c)$ Changes in cell dry weight $(\Lambda) \cdot(b, d)$ Distribution of nitrogen in whole cells $(\Theta)$, in TCA-precipitable material $(O)$, in TCA-supernatant $(\square)$ and in cyanophycin ( $\mathbf{\square})$. Results are means \pm SD.

to cyanophycin contents of $0.05 \%$ of dry weight. Similarly, cyanophycin did not accumulate in nitrogenfixing Gloeothece (not shown). In fact cyanophycin was frequently not detectable at all in either organism under these conditions of exponential growth in $\mathrm{L} / \mathrm{D}$ cycles (cf. Simon, 1987).

\section{Measurement of total nitrogen}

Figs. 2 and 3 show the distribution of nitrogen in different cellular fractions of $A$. cylindrica and Gloeo- thece, respectively, as a function of time. Cyanophycin accounted for less than $1 \%$ of total cell nitrogen and it did not vary across the L/D cycle in either organism. In $A$. cylindrica the total nitrogen content increased predominantly in the light period (Fig. $2 b$ ), which is consistent with the known pattern of nitrogen fixation in this organism. Newly-fixed nitrogen was found in the protein fraction (TCA-precipitable material), which would be consistent with the interpretation that this nitrogen was incorporated into amino acids, and used immediately for protein synthesis. Protein nitrogen also 


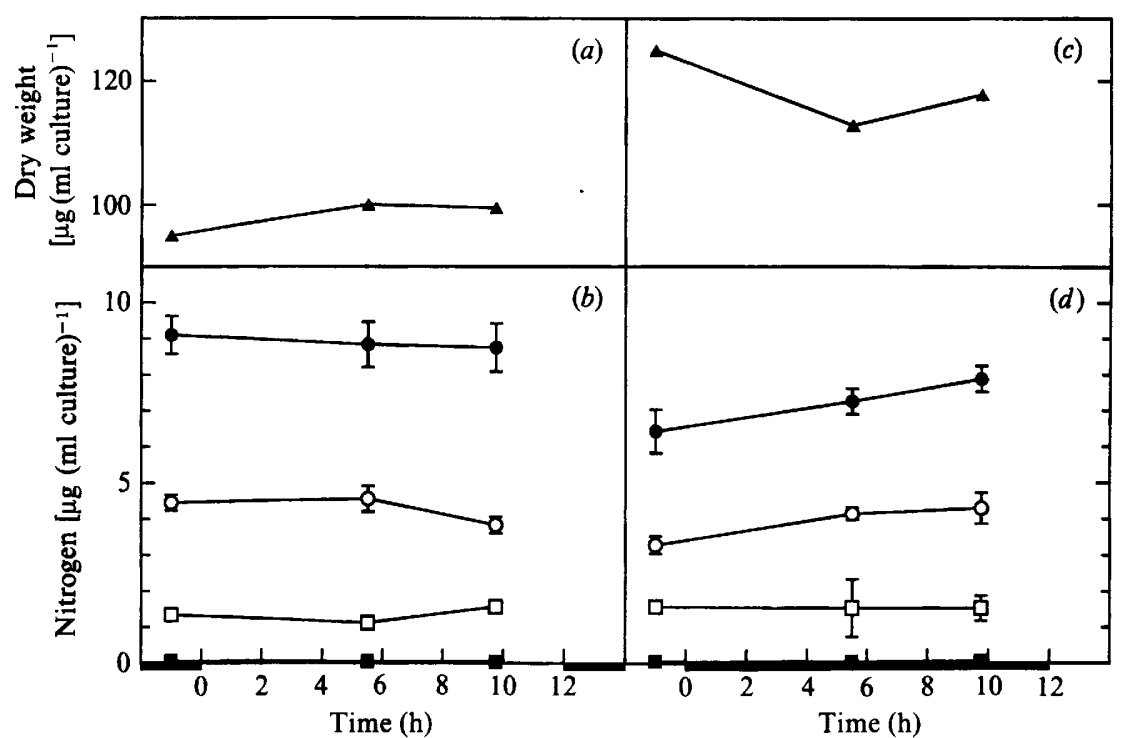

Fig. 3. Distribution of nitrogen in cell fractions of nitrogen-fixing Gloeothece grown on $12 \mathrm{~h} \mathrm{~L} / 12 \mathrm{~h} \mathrm{D}$ cycles under air. Measurements were made during the light $(a, b)$ and dark $(c, d)$ periods. Initial Klett values were $47(a, b)$ and $52(c, d)$. $(a, c)$ Changes in cell dry weight (A). $(b, d)$ Distribution of nitrogen in whole cells $(\Theta)$, in TCA-precipitable material $(O)$, in TCA-supernatant $(\square)$ and in cyanophycin (G). Results are means \pm SD. Twenty-four hours after the first samples were taken, the cell densities had increased to 54 and $60 \mathrm{Klett}$ units, respectively.

increased during the dark period. The increase $(2.5 \mu \mathrm{g}$ $\mathrm{ml}^{-1}$ ) was about $80 \%$ of that observed in the light $\left(3 \cdot 2 \mu \mathrm{g} \mathrm{ml}^{-1}\right)$, which is consistent with the measured rates of protein synthesis (Fig. 1). The increase in protein nitrogen in the dark was also significantly greater than the observed increase in total nitrogen $\left(1.5 \mu \mathrm{g} \mathrm{ml}^{-1}\right)$, which means that non-protein nitrogen must have been used to support the observed protein synthesis. If cyanophycin were the source of this nitrogen its pool size at the end of the light period would need to have been of the order of $1 \mu \mathrm{g} \mathrm{ml}^{-1}$ rather than the measured level $\left(0.1 \mu \mathrm{g} \mathrm{ml}^{-1}\right)$. There is no evidence that the TCA-soluble fraction could have supplied this nitrogen, so the source of extra nitrogen remains unknown (cf. Foy \& Smith, 1980).

In Gloeothece, total nitrogen increased in the dark by $1.4 \mu \mathrm{g} \mathrm{ml}^{-1}$ (Fig. $3 d$ ), which agrees with the expected dark fixation of nitrogen under these conditions. The newly-fixed nitrogen apparently went straight into the protein pool, which increased by $1.0 \mu \mathrm{g} \mathrm{ml}^{-1}$ (Fig. $3 d$ ); there was no indication that any newly-fixed nitrogen entered the cyanophycin pool. As would be expected, total nitrogen remained constant in the light. Little protein synthesis occurred in the light period (Fig. 3b), which is perhaps explicable if all the fixed nitrogen had already been used for protein synthesis in the dark period. Both Klett units and dry weight increased, however (Fig. 3a). These data imply that glycogen accumulates during the light to support nitrogen fixation and protein synthesis in the dark.

\section{Antigenicity of cyanophycin}

Fig. 4 shows the results of a typical ELISA measurement of cyanophycin, using the ascitic fluid produced in mice. The antigen concentration was $2 \mu \mathrm{g}$ per well, and the ascitic fluid was serially diluted from $1: 15$ to $1: 30000$ in antibody buffer. On the basis of these results it was concluded that antibodies directed against cyanophycin had been produced, and that cyanophycin was antigenic.

\section{Development of a radioimmunobinding assay for cyanophycin}

The radioimmunobinding assay procedure described in Methods was first tested on purified cyanophycin, which was spotted on to the nitrocellulose in amounts ranging from 0 to $4 \mu \mathrm{g}$. These concentrations are below the limit of detection by the usual chemical assay for cyanophycin. In this concentration range, bound radioactivity increased linearly with cyanophycin (the correlation coefficient in a linear least squares analysis was 0.9939; result not shown). The lower limit of detection was $0.1 \mu \mathrm{g}$ of cyanophycin.

Experiments were performed to assess the suitability of the assay for detection of cyanophycin in crude cell extracts. These experiments involved comparing results of a radioimmunoassay of crude extracts with conventional assays of cyanophycin purified from the same extracts. Unfortunately, considerable non-specific binding of the primary antibody to proteins in the crude extracts occurred. Such non-specific binding was re- 


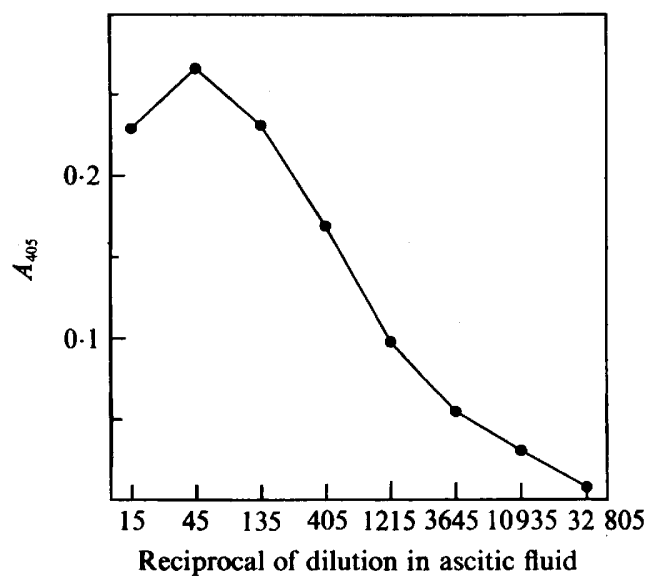

Fig. 4. ELISA assay for anti-cyanophycin antibody. Antibodies were raised in mice and assayed as described in the Methods. The $x$-axis shows successive 1 in 3 dilutions of ascitic fluid starting from 1 in 15 .

duced somewhat by washing the nitrocellulose strips with Triton X-100 (0.1\%) or $3 \mathrm{M}$-urea after addition of the primary antibody, but detection of cyanophycin was still strongly masked by non-specific binding. It was concluded that the radioimmunoassay has limited applicability for assaying cyanophycin in crude extracts. Its main virtue at this stage is that it extends the detection limit of extracted cyanophycin from approximately $2 \mu \mathrm{g}$ (arginine assay) to approximately $0.1 \mu \mathrm{g}$.

\section{An immunochemical approach to cyanophycin turnover}

Experiments were done to find a suitable immunoprecipitation assay for cyanophycin which might allow quantitative measurement of cyanophycin turnover by pulse-chase methodology using labelled arginine. Immunoprecipitation using Staphylococcus aureus protein A (Langone, 1982) was based on the specific procedure of Rice \& Strauss (1982).

To ensure that arginine transport into cells was not rate-limiting in such experiments, the rate of uptake of $\left[{ }^{3} \mathrm{H}\right]$ arginine was determined. When $0.25 \mu \mathrm{Ci}(9.2 \mathrm{kBq})$ $\left[{ }^{3} \mathrm{H}\right]$ arginine $(9.6 \mathrm{pmol})$ was added to $2.5 \mathrm{ml} \mathrm{A}$. cylindrica cells ( $140 \mathrm{Klett}$ units), arginine uptake was rapid and essentially complete within 10-15 min (result not shown).

Despite many experiments, a useful and reliable immunoprecipitation procedure was not developed. The insolubility of cyanophycin itself masked any precipitation of cyanophycin-antibody-protein A conjugates.

\section{Discussion}

The results presented here indicate that when nitrogenfixing $A$. cylindrica is grown on L/D cycles significant amounts of protein synthesis occur in the dark. This implies the presence of a temporary store of fixed nitrogen to supply nitrogen for that protein synthesis in the dark. On the basis of measurements of cyanophycin by two methods, the arginine assay (Fig. 1) and total nitrogen measurements (Fig. 2), it is quite clear that cyanophycin does not supply this nitrogen in exponentially-growing cells. The results also agree with the report by Simon (1987) that cyanophycin levels are always very low during the exponential growth phase in nitrogenfixing $A$. cylindrica, although he was probably referring to cultures grown in continuous light.

The source of nitrogen for protein synthesis during the dark is not clear. The total nitrogen recovered in the cell fractions (protein, soluble fraction and cyanophycin) accounted for approximately $75 \%$ of the nitrogen detected in the whole-cell samples. The pellet fraction contained some green material, indicating the presence of small numbers of unbroken cells, and implying the loss of some nitrogen during the washing steps which preceded cyanophycin extraction. In addition, the cell walls remained insoluble during the washing steps, and therefore the peptidoglycan fraction was not included in totals of subcellular nitrogen. However, although these factors help to explain the discrepancy between wholecell nitrogen and the subcellular fractions, they do not clarify the source of the nitrogen which supports protein synthesis in the dark.

In Gloeothece, nitrogen would be fixed during the dark period, and since most of it appeared to enter the protein pool directly, Gloeothece would not appear to need to accumulate a store of fixed nitrogen in the dark to support protein synthesis in the light. This result disagrees with the data of Mullineaux et al. (1981 b), who reported that dark protein synthesis in Gloeothece was only $15 \%$ of the rate in the light. Their result appears to have been obtained with Gloeothece that had been grown in continuous light and then darkened for the first time during the course of the experiment. Since cells require several days to adapt to alterations in their lighting regime (e.g. Post, 1986, 1987), such cells may not represent suitable material for the experiment.

The ability to accumulate cyanophycin as a temporary store of fixed nitrogen has been suggested to buffer nitrogen-fixing cells against variations in the supply of newly assimilated nitrogen (Carr, 1983; Carr \& Wyman, 1986). The growth of $A$. cylindrica on $L / D$ cycles represents such conditions; the supply of $\mathrm{NH}_{3}$ from nitrogenase is certainly not constant, and protein synthesis makes continued demands for amino acids. There is no indication, however, of net accumulation of cyanophycin during the light to provide fixed nitrogen in the dark. Although nitrogen may cycle into and out of cyanophycin as proposed by Carr (1988), it must turn 
over very rapidly, and consequently could not be used as a temporary nitrogen store under the conditions prevailing in the experiments described here.

To date there is still only circumstantial evidence to support the hypothesis (Carr, 1988) that dynamic cyanophycin metabolism is important in heterocystous cyanobacteria under $\mathrm{N}_{2}$-fixing conditions (Meeks et al., 1977, 1978; Stewart et al., 1975). The ability to synthesize and degrade cyanophycin constitutively would ensure that cyanobacteria are always poised to synthesize cyanophycin if an imbalance in nutrient supply occurs. However, if such a mechanism operates, an imbalance in growth conditions should lead to cyanophycin accumulation. The accompanying paper describes conditions where variations in the supply of fixed nitrogen lead to dynamic cyanophycin metabolism (Mackerras et al., 1990).

The ability to measure cyanophycin turnover would allow Carr's hypothesis to be tested directly under conditions where nitrogen might cycle rapidly into and out of a cyanophycin pool. Our attempts to develop immunological methods for isolating and quantifying cyanophycin were pursued with this aim. However, the insolubility of cyanophycin prevented the use of this approach.

The definition and measurement of growth in photosynthetic cells subjected to $\mathrm{L} / \mathrm{D}$ cycles is complicated. Light-scattering measurements are biased towards increases in total and individual cell mass, rather than increase in cell number (Brock et al., 1984; Mallette, 1969). Any measured increase in biomass during the light period in cells grown on a L/D cycle cannot be considered purely as growth, because it also includes carbohydrate which accumulates to cope with the coming dark period (Mur, 1983; Smith, 1983). The protein synthesis observed in the dark must occur at the expense of glycogen stored during the preceding light period. Net dry weight would not increase under these conditions and, in fact, should decrease because $\mathrm{CO}_{2}$ is released as respiratory processes supply the necessary energy. Consequently light-scattering measurements alone do not show the whole picture. Similar problems with definitions of growth have occurred during studies of nitrogen starvation. It is well known that carbohydrate accumulates under these conditions (e.g. Allen \& Smith, 1969; Lehmann \& Wober, 1976) but this cannot accurately be called growth since protein accumulation ceases (cf. Boussiba \& Richmond, 1980).

The experiments reported in this paper were designed to test the possibility that cyanophycin synthesis and degradation were important in nitrogen-fixing cells grown on L/D cycles where the ability to temporarily fill and deplete a store of fixed nitrogen would indeed buffer metabolic requirements against variations in nitrogen supply. Although the results indicate that $A$. cylindrica needs a store of fixed nitrogen to support protein synthesis in the dark, there was no evidence that cyanophycin fulfilled that role. Thus, the high activities of cyanophycin synthetase and cyanophycinase found in heterocysts and the role of the polar plugs thought to be rich in cyanophycin remain to be explained.

\begin{abstract}
We thank Mrs Nola M. de Chazal for technical assistance. We also acknowledge the financial assistance of the Australian Research Grants Scheme and the Faculties Research Fund of the Australian National University.
\end{abstract}

\section{References}

Allen, M. B. \& ARNoN, D. I. (1955). Studies on nitrogen-fixing bluegreen algae. I. Growth and nitrogen fixation by Anabaena cylindrica Lemm. Plant Physiology 30, 366-372.

Allen, M. M. (1984). Cyanobacterial cell inclusions. Annual Review of Microbiology 38, 1-25.

Allen, M. M. \& SMITH, A. J. (1969). Nitrogen chlorosis in blue-green algae. Archives of Microbiology 69, 114-120.

Bergersen, F. J. (1980). Measurement of nitrogen fixation by direct means. In Methods for Evaluating Biological Nitrogen Fixation, pp. 66-110. Edited by F. J. Bergersen. Chichester: John Wiley.

Bradford, M. M. (1976). A rapid and sensitive method for the quantitation of microgram quantities of protein utilizing the principle of protein-dye binding. Analytical Biochemistry 72, 248254.

Brock, T. D., Smith, D. W. \& Madigan, M. T. (1984). Biology of Microorganisms, 4th edn, p. 218. New Jersey: Prentice Hall.

Boussiba, S. \& RICHMOND, A. E. (1980). C-Phycocyanin as a storage protein in the blue-green alga Spirulina platensis. Archives of Microbiology 125, 143-147.

CARR, N. G. (1983). Biochemical aspects of heterocyst differentiation and function. In Photosynthetic Prokaryotes: Cell Differentiation and Function, pp. 265-280. Edited by G. C. Papageorgiou and L. Packer. New York \& Amsterdam: Elsevier.

CARR, N. G. (1988). Nitrogen reserves and dynamic reservoirs in cyanobacteria. In Biochemistry of the Algae and Cyanobacteria. Annual Proceedings of the Phytochemical Society of Europe, pp. 1321. Edited by L. J. Rogers and J. R. Gallon. Oxford: Clarendon Press.

CARR, N. G. \& WyMan, M. (1986). Cyanobacteria: their biology in relation to the oceanic picoplankton. Canadian Bulletin of Fisheries and Aquatic Sciences 214, 159-204.

Daday, A., Platz, R. A. \& SMIrH, G. D. (1977). Anaerobic and aerobic hydrogen gas formation by the blue-green alga Anabaena cylindrica. Applied and Environmental Microbiology 34, 478-483.

Daday, A., Mackerras, A. H. \& SMITH, G. D. (1985). The effect of nickel on hydrogen metabolism and nitrogen fixation in the cyanobacterium Anabaena cylindrica. Journal of General Microbiology 131, 231-238.

Daday, A., Mackerras, A. H. \& Smith, G. D. (1988). A role for nickel in cyanobacterial nitrogen fixation and growth via cyanophycin metabolism. Journal of General Microbiology 134, 2659-2663.

Davis, J. W., Angel, J. M. \& Bowen, J. M. (1984). A quantitative immunobinding radioimmunoassay for antigens attached to nitrocellulose paper. Journal of Immunological Methods 67, 271-278.

FoY, R. H. \& SMITH, R. V. (1980). The role of carbohydrate accumulation in the growth of planktonic Oscillatoria species. British Phycological Journal 15, 139-150.

GupTA, M. \& CARR, N. G. (1981). Enzyme activities related to cyanophycin metabolism in heterocysts and vegetative cells of Anabaena spp. Journal of General Microbiology 125, 17-23. 
Kallas, T., RippKa, R., Coursin, T., Rebiere, M.-C., Tandeau DE MARSAC, N. \& CoHEN-BAZIRE, G. (1983). Aerobic nitrogen fixation by non-heterocystous cyanobacteria. In Photosynthetic Prokaryotes: Cell Differentiation and Function, pp. 281-302. Edited by G. C. Papageorgiou \& L. Packer. New York \& Amsterdam: Elsevier.

LA DUCA, F. M., DANG, C. V. \& Bell, W. R. (1986). Application of a nitrocellulose immunoassay for quantitation of proteins secreted in culture media. Analytical Biochemistry 158, 262-267.

LANGONE, J. J. (1982). Protein A of Staphylococcus aureus and related immunoglobulin receptors produced by streptococci and pneumococci. Advances in Immunology 32, 157-252.

LAWRY, N. H. \& SimON, R. D. (1982). The normal and induced occurrence of cyanophycin inclusion bodies in several blue-green algae. Journal of Phycology 18, 391-399.

LEHMANN, M. \& WOBER, G. (1976). Accumulation, mobilization and turn-over of glycogen in the blue-green bacterium Anacystis nidulans. Archives of Microbiology 111, 93-97.

MaCkerras, A. H., de Chazal, N. M. \& SMith, G. D. (1990). Transient accumulations of cyanophycin in Anabaena cylindrica and Synechocystis 6308. Journal of General Microbiology 136, 2057-2065.

MalletTE, M. F. (1969). Evaluation of growth by physical and chemical means. Methods in Microbiology 1, 521-566.

Meeks, J. C., Wolk, C. P., Thomas, J., LockaU, W., Shaffer, P. W., Austin, S. M., Chien, W.-S. \& Galonsky, A. (1977). The pathways of assimilation of ${ }^{13} \mathrm{NH}_{4}^{+}$by the cyanobacterium, Anabaena cylindrica. Journal of Biological Chemistry 252, 7894-7900.

Meeks, J. C., Wolk, C. P., Lockau, W., Schilling, N., Shaffer, P. W. \& CHIEN, W.-S. (1978). Pathways of assimilation of $\left[{ }^{13} \mathrm{~N}\right] \mathrm{N}_{2}$ and ${ }^{13} \mathrm{NH}_{4}^{+}$by cyanobacteria with and without heterocysts. Journal of Bacteriology 134, 125-130.

MESSINEO, L. (1966). Modification of the Sakaguchi reaction: spectrophotometric determination of arginine in proteins without previous hydrolysis. Archives of Biochemistry and Biophysics 117, 534540.

Mitsui, A., Kumazawa, S., Takahashi, A., Ikemoto, H., Cao S. \& ARAI, T. (1986). Strategy by which nitrogen-fixing unicellular cyanobacteria grow photoautotrophically. Nature, London 323, 720-722.

MullineauX, P. M., Chaplin, A. E. \& Gallon, J. R. (1980). Effects of a light to dark transition on carbon reserves, nitrogen fixation and ATP concentration in cultures of Gloeocapsa (Gloeothece) sp. 1430/3. Journal of General Microbiology 120, 227-232.

Mullineaux, P. M., Gallon, J. R. \& Chaplin, A. E. (1981a). Acetylene reduction (nitrogen fixation) by cyanobacteria grown under alternating light-dark cycles. FEMS Microbiology Letters 10, 245-247.
Mullineaux, P. M., Gallon, J. R. \& Chaplin, A. E. (1981 $b$ ) Nitrogen fixation in cultures of the cyanobacterium Gloeocapsa (Gloeothece) sp. 1430/3 incubated in the dark. Journal of General Microbiology 124, 141-146.

MUR, L. R. (1983). Some aspects of the ecophysiology of cyanobacteria. Annales de Microbiologie 134B, 61-72.

Ownby, J. D., Shannahan, M. \& Hood, E. (1979). Protein synthesis and degradation in Anabaena during nitrogen starvation. Journal of General Microbiology 110, 255-261.

Post, A. F. (1986). Transient state characteristics of adaptation to changes in light conditions for the cyanobacterium Oscillatoria agardhii. I. Pigmentation and photosynthesis. Archives of Microbiology 145, 353-357.

Post, A. F. (1987). Transient state characteristics of changes in light conditions for the cyanobacteria Oscillatoria agardhii. II. Dynamics in cellular contents and growth rates. Archives of Microbiology 149, 19-23.

Rice, C. M. \& STrauss, J. H. (1982). Use of staphylococcal protein A as an immunological reagent. Journal of Molecular Biology 154, 325348.

Romero, J. M. \& LARA, C. (1987). Photosynthetic assimilation of $\mathrm{NO}_{3}^{-}$ by intact cells of the cyanobacterium Anacystis nidulans. Plant Physiology 83, 208-212.

SHUTER, B. (1979). A model of physiological adaptation in unicellular algae. Journal of Theoretical Biology 78, 519-552.

SimoN, R. D. (1971). Cyanophycin granules from the blue-green alga Anabaena cylindrica: a reserve material consisting of copolymers of aspartic acid and arginine. Proceedings of the National Academy of Sciences of the United States of America 68, 265-267.

SimON, R. D. (1973). Measurement of the cyanophycin granule polypeptide contained in the blue-green alga Anabaena cylindrica. Journal of Bacteriology 114, 1213-1216.

SIMON, R. D. (1987). Inclusion bodies in the cyanobacteria : cyanophycin, polyphosphate, polyhedral bodies. In The Cyanobacteria, pp. 199-225. Edited by P. Fay \& C. Van Baalen. Amsterdam \& New York: Elsevier.

SMITH, A. J. (1983). Modes of cyanobacterial carbon metabolism. Annales de Microbiologie 134B, 93-113.

Stewart, W. D. P., Haystead, A. \& Dharmawardene, M. W. N. (1975). Nitrogen assimilation and metabolism in blue-green algae. In Nitrogen Fixation in Free-living Micro-organisms, pp. 129-158. Edited by W. D. P. Stewart. Cambridge: Cambridge University Press.

Tikasingh, E. S., SPENCE, I. \& Downs, W. G. (1966). Use of adjuvant and sarcoma 180 cells in production of mouse hyperimmune ascitic fluids to arboviruses. American Journal of Tropical Medicine and Hygiene 15, 219-226. 